\title{
Analysis Relationship Family Support and Health Cadre with Elderly Hypertension Practice in Controlling Health at Primary Health Care Mranggen Demak
}

\section{Ninin Irani ${ }^{1}$}

1 Primary Health Care of Mraggen Demak

\begin{tabular}{|c|c|}
\hline Article Info & Abstract \\
\hline $\begin{array}{l}\text { Article History: } \\
\text { Accepted May 7th, } 2019 \\
\text { Key words: } \\
\text { Practice; Elderly; Health } \\
\text { Control; Hypertension }\end{array}$ & $\begin{array}{l}\text { Hypertension is a major risk factor for cardiovascular disease which is the } \\
\text { leading cause of death in Indonesia. Data Research Department of Health in } \\
\text { 2005, showed hypertension and cardiovascular disease is still quite high } \\
\text { and even tends to increase with the lifestyle that much of the behavior of } \\
\text { healthy and clean life, high cost of treatment of hypertension, erroneous } \\
\text { perception of the public accompanied by a lack of safety facilities } \\
\text { hypertension, Hypertension is actually a disease that can be prevented if } \\
\text { the risk factors can be controlled and healthy behaviors (healthy behavior) } \\
\text { which practices or activities related to efforts to maintain, control and } \\
\text { improve health. Data from Demak district health department, the incidence } \\
\text { of hypertension has increased within the last three years. The aim of this } \\
\text { study was to determine the relationship of family support and cadres with } \\
\text { elderly Hypertension practices in controlling health in Puskesmas } \\
\text { Mranggen, Demak by using a cross-sectional study with a quantitative } \\
\text { approach. The sample size for a quantitative approach is } 285 \text { respondents } \\
\text { (total sampling). The data were analyzed using univariate, bivariate with } \\
\text { chi-square. The results showed an association between family support for } \\
\text { elderly people who suffer from hypertension with the practice of elderly } \\
\text { hypertension in controlling health (p = 0.048), there is a relationship } \\
\text { between support for health workers to the elderly who suffer from } \\
\text { hypertension with Practice elderly hypertension in controlling health (p = } \\
\text { 0.049). Advice to the puskesmas officers in order to improve the quality of } \\
\text { health care, home visits, provide health education particularly on } \\
\text { controlling health benefits for elderly hypertension and cross-sectoral } \\
\text { cooperation in the implementation of an integrated program of coaching } \\
\text { post (posbindu) elderly. }\end{array}$ \\
\hline
\end{tabular}

\section{INTRODUCTION}

Hypertension is a major risk factor for cardiovascular disease which is the leading cause of death in Indonesia. Data Research Department of Health in 2005, showed hypertension and cardiovascular disease is still quite high and even tends to increase with the lifestyle that is far from healthy and hygienic behavior, high cost of treatment of hypertension, accompanied by a lack of safety facilities hypertension. If

Corresponding author:

Ninin Irani

nininirani.ni@gmail.com

South East Asia Nursing Research, Vol 1 No 1, June 2019

ISSN:2685-032X

DOI: https://doi.org/10.26714/seanr.1.1.2019.7-13 
left untreated hypertension, the blood pressure will continue to increase gradually, resulting in the excessive workload of the heart. ${ }^{1}$ The excessive workload of the heart that will someday result in serious damage to the blood vessels and organs such as the heart, kidneys, eyes, and even rupture of capillaries in the brain, or better known by the name of a stroke.

Hypertension, also known as a heterogeneous group of diseases, which can affect anyone of various age groups, the elderly are the age group most susceptible to hypertension, as well as the social economy. The tendency of changing lifestyles as a result of urbanization, modernization, and globalization led to a number of risk factors that may increase morbidity hypertension. ${ }^{2} 38.8 \%$ of the elderly who suffer from hypertension, only $50 \%$ were treated regularly (controlled hypertension) and only half of the control well. That is, of all people with hypertension in Indonesia that is wellcontrolled amount below $10 \% .^{3,4}$ It is easy to understand because it does not give symptoms of hypertension. Such conditions appropriate to the nature of hypertension as the silent killer (silent killers), because many people do not pay attention to a disease that is sometimes taken lightly by them, without knowing if the disease is dangerous from a variety of disorders that more fatal for example, abnormal blood vessels, heart (cardiovascular) and kidney problems and many patients who come for treatment when already severe vascular damage. ${ }^{5}$

Hypertension is actually a disease that can be prevented if the risk factors can be controlled and healthy behaviors (healthy behavior) that the conduct or activities related to efforts to maintain and improve health. Those efforts include monitoring blood pressure regularly, healthy living programs without smoke, increased physical activity/exercise, a healthy diet with caloric balance through the consumption of high-fiber, low-fat and lowsalt, it is a combination of independent efforts by individuals / communities and supported by the existing health care program and should be done as early as possible, in hypertensive patients require regular maintenance in order to know their blood pressure. Patients with hypertension should perform routine checks that hypertension in misery can be controlled well. ${ }^{2}$

Data from Demak district health offices, the incidence of hypertension has increased within the last three years, in 2011 was 889 cases $(13.6 \%)$, the year 2012 amounted to 1235 cases (16.5\%) and the year 2013 by $2173(17,8 \%)$ and ranked first 10 elderly diseases. Data in Demak Mranggen health center in the last 3 years, in 2011 was 935 cases (12\%), in 2012 as many as 1150 cases (14.5\%) and in 2013 amounted to 1325 cases (16.3\%) and is the second highest after joint disease of 1570 cases (21\%). Based on reporting records of Posyandu elderly Source Healthy Kale village, turns hypertension in the elderly was ranked first in the amount of $64 \%$ (130 people), joint disease $20 \%$ ( 41 people) of 203 elderly who are registered as members of Posyandu. Of hypertensive patients is only $32 \%$ (42 people) who carry out regular inspections of each month, the rest do not do on a regular basis. ${ }^{1}$

From the report the practice of nursing care performed S1 students of Nursing, the University of Muhammadiyah Semarang in Puskesmas Mranggen in January-March 2014, of 318 elderly with hypertension, 145 (46\%) perform a routine check on health services, the rest do not conduct regular inspections, it is because the reason does not have money for treatment, felt bad for being a burden his family, no escort because they live alone, considers the disease is a mild disease that does not need to be checked regularly.

In a society often found misconceptions about the illness. Many members of the 
public when they are already sick can not work or is not able to get out of bed. Communities affected by the disease but do not feel pain (disease but no illness) will not act anything against the disease, but if they are affected by the disease and also feel pain then there will be a business and kinds of behavior, ie no action (no action), acting treat yourself (self-treatment) and seek traditional treatment started (traditional remedy), up to modern medical facilities organized by practitioners (private modern medicine). ${ }^{6}$ Someone will take preventive action is influenced by demographic variables (education, knowledge, age, and occupation) of individuals as well as for instructions to behave (cues to action) alleged right to start the process of behavior, which is derived from information or advice on the health problems of hypertension. Health behaviors someone starts that behavior is a function of one's intention to act (behavior intention), social support from family and the surrounding community (social support), lack of access to health services (accessibility of health care), personal autonomy of people concerned in terms of taking the actions or decisions (personal autonomy) as well as the situation allows it to act (action situation). ${ }^{7}$

\section{METHODS}

This type of research is explanatory research using a cross-sectional approach. The population in this study were all elderly with hypertension, aged $\geq 60$ years or older and live in the region Puskesmas Mranggen Demak between the months of June to December 2014. The sample size in this study is total sampling that all the elderly who suffer from hypertension, aged $\geq 60$ years or older and live in the region Puskesmas Mranggen Demak, as many as 285 people.

Measuring tool used to obtain quantitative data in this study is a questionnaire in the form of written questions to uncover the independent and dependent variables. To prove the validity of the questionnaire used in this study has been tested for validity and reliability, the trial questionnaires in Puskesmas Karangawen Demak with the number of respondents 30 elderly. Validity test conducted with product moment correlation test, while the reliability test using Cronbach alpha statistic test.

Independent variables: family support, and support health workers while the dependent variable was the practice in controlling hypertension elderly health. Once the data is collected, then processed by examining the questionnaire, editing, coding, scoring and tabulating the data analyzed. Data analysis aimed to determine the relationship between independent variables with the dependent variable. In addition, the analysis was also used to test the research hypothesis. Analysis techniques used include: univariate, is used to analyze the variables - variables that exist in descriptive by calculating the frequency distribution and proportion. The bivariate analysis consists of: (1) cross tabulation analysis is used to summarize, determine the distribution of data and can also be used to analyze descriptively. (2) The comparative analysis (correlation test) as the basis for testing the research hypothesis. This analysis using Chi-Square test with $\alpha=0.05$.

\section{RESULTS}

\section{Practice in controlling health Elderly}

Average practices committed by the respondent in controlling health was $5.47 \pm$ 1.721 with a minimum of 2 and a maximum value of 8. Practice elderly hypertension in controlling health have largely been good, that is $69.1 \%$ and less by $30.9 \%$, but there are about $59.6 \%$ do not exercise regularly, $44.2 \%$ were still smoking and a diet as recommended by $35.1 \%$ and $33.7 \%$ still consume alcoholic beverages. 


\section{Family Support}

Average family support against the respondent was $9.04 \pm 1.959$ with a minimum of 2 and a maximum value of 11 . The highest level of support from family is good support and the support of $88.1 \%$ less as much as $11.9 \%$. Most of the respondents have the support of the family, but in practice control the health of the respondents did not receive full support from the family, it is pointed out there are still $26.3 \%$ of families do not take the time to the respondents, $24.9 \%$ of respondents did not want to deliver to check the health stewardship , $21.8 \%$ of families do not support all the activities of the respondents and $18.6 \%$ of families do not bear all the costs of treatment responders.

\section{Support Health Cadre}

Average support cadres of the respondents were $2.86 \pm 2.152$ with a minimum value of 1 and a maximum of 7 . The level of support from most health cadres is good support at $51.2 \%$ and less support as much as $48.8 \%$. Respondents who have the support of a cadre of good health and a lack of support is quite balanced, this is indicated approximately $58.2 \%$ health worker gives advice about the disease that affects the elderly, $55.1 \%$ of health volunteers reminded to conduct periodic examinations, $53,3 \%$ taught how to care and $52.3 \%$ were advised to rest, while support health volunteers demonstrated less than $87 \%$ volunteer health worker to deliver health services, $79.3 \%$ did not teach gymnastics, and $67.4 \%$ are not health workers organize Posyandu elderly.

From the analysis of the relationship between health workers to support the elderly who suffer from hypertension in the elderly hypertension Practice in controlling health showed that there were $98(75.4 \%)$ of respondents who have less support health cadres to practice good health control.
While respondents who have the support of good health cadres there are 99 (63.9\%) who practice good health control, and that there are as many as 32 (24.6\%) of respondents who have less support health cadres to practice controlling ill health. While respondents who have the support of good health cadres there were 56 (36.1\%) who practice controlling ill health. The results of the statistical test Chi-Square test obtained by value $\mathrm{p}=0,049$ with an error rate of $5 \%$, it can be concluded that there is a relationship between health workers to support the elderly who suffer from hypertension in the elderly hypertension Practice in controlling health

\section{DISCUSSION}

The support given by the family of the elderly with hypertension who control practices in good health, is they have been warned to want to check, reminded to take his medication regularly, delivering check, help with the cost check, remind to reduce salt, adequate rest, quitting smoking, advise many worships and pray, while the family of advanced age is not doing well health control practices revealed that they have made efforts reminded to check, recommends to check, eat right, do a heavy work

The size of the support provided by the family is also closely linked to the family's understanding of the perception of vulnerability, perceived severity, perceived benefits, perceived barriers, and access to health services.

From the analysis of the relationship between family support for elderly people who suffer from hypertension in elderly hypertensive practices in controlling health showed that there were 18 (52.9\%) of respondents who have less family support practices with good control of their health. While respondents who have good family support there were 179 (71.3\%) who practice good health control, and that there are as many as $16(47.1 \%)$ of respondents 
who have less family support practice controlling ill health. While respondents who have good family support there were $72(28.7 \%)$ who practice controlling ill health.

The results of the statistical test Chi-Square test obtained by value $\mathrm{p}=0,048$ with an error rate of $5 \%$, it can be concluded that there is a relationship between family support for elderly people who suffer from hypertension in elderly hypertensive practices in controlling health.

Humans as social beings can not live alone without the help of others. Physical needs (clothing, food, housing), social needs (association, recognition, school, work) and psychological needs including curiosity, a sense of security, feelings of religiosity, not be fulfilled without the help of others. ${ }^{8}$ Especially if the person is facing problems, whether mild or severe. At moments like that, someone would seek social support from the people around him, so he feels valued, cared for and loved.

Social support can be regarded as something beneficial situation, providing assistance for individuals obtained from another person who can be trusted and as the availability and willingness of those means, which can be trusted to assist, encourage, receive, and keep individual. From these circumstances, the individual will know that other people pay attention, respect, and love. The family is a source of social support for family relationships to create a relationship of mutual trust. The individual as a member of the family will make the family as a collection of hope, a story, ask, and issuing complaints when the individual is experiencing problems. ${ }^{9}$ According to Green's theory that social support is one factor that strengthens a person to perform a specific behavior. ${ }^{7}$

Family support can include emotional support, instrumental, information, and assessments. ${ }^{10}$ Emotional support involves the physical strength and the desire to believe in others so that the individuals concerned became convinced that others are able to provide love and affection to him, support Instrumental, such as the provision of means to facilitate or help others as an example is the equipment, supplies, and Other supporting facilities and including providing a timely opportunity. Informative support for the provision of information to resolve personal problems, namely the provision of advice, guidance, and other information required by the individuals concerned as well as support for assessment in the form of social roles that include feedback, social comparison, and affirmation (approval).

Giving support to the elderly requires an understanding of the family about the perception of vulnerability, perceived severity, perceived benefits, perceived barriers, access to health services and presence (availability) as well as the accuracy / appropriateness (adequacy) of such assistance for the elderly, so as not to cause social support given misunderstood and not well targeted. If the elderly (for various reasons) are no longer able to understand the significance of social support, it is necessary not only social support or maintenance service but socially (social care) completely. ${ }^{11}$ Support has been done by the families in this study were mostly families have made efforts observing condition/disease state, suggesting to pray, remind to always obey the doctor's advice, suggesting to adequate rest, and provide information about the disease.

Results cross check with the family of respondents indicated that the majority of families of respondents have understood recurrence risk factors, complications may occur, along with the health benefits of exercise control obstacles that may occur as well as access gained in an effort to control the practice of health of elderly hypertensive. The support provided by the family tried to remind to want to check, reminded to take his medication regularly, 
delivering the check, help with the cost check, remind to reduce salt, adequate rest, smoking cessation, suggesting to many worships and pray. This suggests that with good family support would encourage elderly hypertensive to practice good health control anyway.

Social support has an important role to prevent health threats, ${ }^{10}$ high social support would make the elderly more optimistic in the face of today's life and future, more skilled in meeting the psychological needs and have a higher system, as well as lower levels of anxiety, enhance interpersonal skills, have the ability to achieve what they want and be able to guide the elderly to adapt to stress that health problems are being encountered can be resolved properly and is able to perform optimal health control practices.

Social support for the elderly is very necessary for the elderly themselves are still able to understand the meaning of social support such as a supporter/sustainer of life, but the life of the elderly is often found that not all elderly people are able to understand the social support from others, so even though he had received social support but still Just indicate dissatisfaction, which is shown by way grumble, disappointed, upset and so forth. This can happen because of the support provided is not sufficient, the elderly feel no need to be assisted or worry too much emotionally that do not pay attention to the support provided, the support provided is not in accordance with what is required of elderly, a source of support for setting a bad example for the elderly, as do suggest unhealthy behaviors and to maintain or support the elderly in doing anything it wants. This situation can disrupt health control practices should be done by the elderly and causes the elderly to become dependent on others.

In this study support given by health workers include: remind the elderly to carry out checks at regular intervals, suggesting to many breaks, dropping to health services, provide advice about the disease, the elderly Posyandu organize, teach gymnastics elderly and teach how to care. There is some support for health cadres perceived by the respondents is not optimal they are escorted to health care, teaching gymnastics elderly and organizing Posyandu, this is due to the limited number of health volunteers are active in every village, most of the implementation of Posyandu still join the Posyandu toddler,

While the results of cross-checking with the families of the respondents about the support given to elderly hypertensive cadres showed the majority of respondents said that family health volunteers have held Posyandu, gymnastics, giving advice about the disease, and taught to live a healthy life. Meanwhile, in the opinion of its own health workers, they have been warned to check, suggesting to many breaks, advise, encourage and teach you how to care to posyandu.

Thus, the better support health volunteers to elderly hypertension will increase efforts to elderly hypertension to control their health and supported by a good understanding of the factors that are at risk of recurrence, complications may occur, the benefits to control health along with the obstacles that may occur and access gained in an effort to control the practice of health of elderly hypertension is the ability to provide support to elderly hypertensive to practice health control will also increase.

\section{CONCLUSION}

From the results of the study showed that $69.1 \%$ of respondents have good health control practices and the remaining 30.9\% had less health control practices, among others: there are about $59.6 \%$ do not exercise regularly, $44.2 \%$ still smoke and not on a diet as recommended by $35.1 \%$ and $33.7 \%$ still consume alcoholic beverages. $88.1 \%$ of respondents get good 
family support and the remaining $11.9 \%$ have less family support. $51.2 \%$ of respondents have the support of good health cadres and the remaining $48.8 \%$ less to get the support of the health cadres. $71.9 \%$ of respondents get access to good health services and $28.1 \%$ had less access to health services. There is a relationship between family support for elderly people who suffer from hypertension in elderly hypertensive practices in controlling health. Less family support, health management practices will be less as well. There is a relationship between health cadre support for elderly people who suffer from hypertension in elderly hypertension practices in controlling health. Support cadre ill health, health management practices will be less as well.

\section{CONFLICTS OF INTEREST}

The author declare that none of her had any conflict of interests.

\section{REFERENCES}

1. Kemenkes. Profil Kesehatan Jawa Tengah Tahun 2015. Tengah DKPJ, editor. Semarang: Dinas Kesehatan Provinsi Jawa Tengah; 2015.

2. Rahajeng E, Tuminah S. Prevalensi hipertensi dan determinannya di Indonesia. Maj Kedokt Indones. 2009;59(12):580-7.

3. Whelton PK, He J, Muntner P. Prevalence, awareness, treatment and control of hypertension in North America, North Africa and Asia. J Hum Hypertens [Internet]. 2004 Aug 22;18(8):545-51. Available from: http://www.nature.com/articles/1001701

4. JULIUS S. Current Trends in the Treatment of Hypertension: A Mixed Picture. Am J Hypertens [Internet]. 1997 Dec 1;10(12):300S-305S. Available from: https://academic.oup.com/ajh/articlelookup/doi/10.1016/S0895-7061(97)00389-0

5. Hoel D, Howard RB, Gifford RW. Hypertension. Postgrad Med $\quad$ [Internet]. 1997 Feb;101(2):116-21. Available from: http://www.tandfonline.com/doi/full/10.381 0/pgm.1997.02.155
6. Notoatmodjo S. Promosi Kesehatan: Teori dan Aplikasi. Jakarta: PT. Asdi Mahasatya; 2005.

7. Notoatmodjo S. Ilmu Kesehatan Masyarakat Prinsip-Prinsip Dasar. Jakarta: PT. Rineka Cipta; 2003.

8. Potter, P. A., Perry, A. G., Stockert, P., \& Hall A. Fundamental of Nursing E-Book. Elsevier; 2016.

9. Nasrudin E. Psikologi Manajemen. Bandung: Pustaka Setia; 2010.

10. Budiman NA, Istiarti T, BM S. Faktor-Faktor Yang Berhubungan Dengan Praktik Wanita Pekerja Seks (WPS) Jalanan Dalam Upaya Pencegahan IMS Dan HIV/AIDS Di Sekitar Alun-Alun Dan Candi Prambanan Kabupaten Klaten. J Promosi Kesehat Indones [Internet]. 2008;3(2):120-6. Available from: https://ejournal.undip.ac.id/index.php/jpki/ar ticle/view/2542

11. Mahanani N. Faktor-Faktor Yang Berhubungan Dengan Perawatan Diri Kusta Pada Penderita Kusta Di Puskesmas Kunduran Kecamatan Kunduran Kabupaten Blora Tahun 2011. 2013; Available from: https://lib.unnes.ac.id/18240/ 